\section{Bipin Chaurasia, MS*}

Harsh Deora, MCh, DNB (D)

Nasser M. F. El-Ghandour, MD ${ }^{\S}$

Nelson M. Oyesiku, MD, PhD?

Raushan Kumar Chaurasia, MOll

Michael Schulder, MD\#

Jose Antonio Soriano Sanchez,

MD**

Mario Teo, MD, FRCS ${ }^{\ddagger \neq}$

Juha Hernesniemi, MD ${ }^{\S \S}$

Joseph Raynor Linzey, MD, MS

Theodore H. Schwartz, MDIIII

Aaron A. Cohen-Gadol, MD, MSc,

MBA\#\#

Michael Lawton, MD***

Giuseppe Umana, MD

Jorge Mura, MD ${ }^{\S \S \S}$

Andre Grotenhuis, MD, PhD โศศา

Ajit K. Sinha, MCh ||||||

Henry W. S. Schroeder, MD,

PhD\#\#

Sabareesh Natarajan, MD MS****

Michael E. Sughrue, MD

Robert F. Spetzler, MD ${ }^{\S \S \S}$

Katharine Drummond, MD,

FRACS ๆทๆๆ

Rokuya Tanikawa, MD|||||||

Paulo Abdo do Seixo Kadri,

MD\#\#\#\#

Yoko Kato, MD, PhD*****

Charles Teo, AM, FRACS

Ashish Suri, MCh ${ }^{\S \S \S \S \S ~}$

Santino Ottavio Tomasi, MD

Peter A. Winkler, MD, PhD ๆศทาก

Gianluca Scalia, MD||l|||||||

Nicolas Sampron, MD, PhD\#\#\#\#

Lukas Rasulic, MD, PhD******

Paolo Cappabianca, MD

Marco M. Fontanella, MD

Edward R. Laws, Jr, MD ๆๆๆๆๆๆ

*Department of Neurosurgery, Neurosurgery Clinic, Birgunj, Nepal; ${ }^{\ddagger}$ Department of Neurosurgery, National Institute of Mental Health and Neuroscience, Bangalore, Karnataka, India;

(Continued on next page)

\section{Correspondence:}

Bipin Chaurasia, MS,

Department of Neurosurgery,

Neurosurgery Clinic,

Birgunj, Nepal-44300.

Email: trozexa@gmail.com

Received, May 27, 2020.

Accepted, June 10, 2020.

Copyright (C) 2020 by the

Congress of Neurological Surgeons

\title{
In Memoriam: A Memoir for Our Fallen "Heroes"
}

Even though neurosurgeons exercise these enormous and versatile skills, the COVID-19 pandemic has shaken the fabrics of the global neurosurgical family, jeopardizing human lives, and forcing the entire world to be locked down. We stand on the shoulders of the giants and will not forget their examples and their teachings. We will work to the best of our ability to honor their memory. Professor Harvey Cushing said: "When to take great risks; when to withdraw in the face of unexpected difficulties; whether to force an attempted enucleation of a pathologically favorable tumor to its completion with the prospect of an operative fatality, or to abandon the procedure short of completeness with the certainty that after months or years even greater risks may have to be faced at a subsequent session-all these require surgical judgment which is a matter of long experience." It is up to us, therefore, to keep on the noble path that we have decided to undertake, to accumulate the surgical experience that these icons have shown us, the fruit of sacrifice and obstinacy. Our tribute goes to them; we will always remember their excellent work and their brilliant careers that will continue to enlighten all of us.

KEY WORDS: COVID-19, Neurosurgeons, Neurosurgery, Obituary

Neurosurgery 0:1-3, 2020 DOI:10.1093/neuros/nyaa314 www.neurosurgery-online.com

$\mathbf{T}$ he international neurosurgical community was deeply affected by the COVID-19 pandemic. A considerable number of neurosurgeons passed away. This memorial is intended to commemorate our colleagues who succumbed during the first 4 mo. We have included those of whom we know (Table). We regret and apologize for any oversight.

The first known and recorded death occurred in Wuhan, the epicentre of the pandemic. Dr Liu Zhiming was the Director of the Neurosurgical Department of the Third Municipal Hospital of Wuhan, which was among the first of the group of 50 hospitals designated for the treatment of novel coronavirus pneumonia. He operated on a pituitary tumor through trans-sphenoidal route. Many of those involved became COVID positive. He, too, became infected and died of respiratory failure in the ICU on February 18, 2020 at the age of $54 \mathrm{yr}$.

Dr Hugo Diez Perez from Paraguay was the first neurosurgeon outside China to die from COVID-19. He practiced at Baptist Medical Centre for $22 \mathrm{yr}$ and was the founder of the Paraguayan Neurosurgery Society. He died on March 20, 2020 at the age of 57.
Dr James T. Goodrich, the American pediatric neurosurgeon, fell victim to COVID-19 on March 30, 2020 at the age of 73. He was the Director of the Division of Paediatric Neurosurgery and Professor of Clinical Neurological Surgery, and of Paediatric, Plastic, and Reconstructive Surgery at the Albert Einstein College of Medicine and Montefiore Medical Centre in the Bronx, New York. Dr Goodrich was well known for his series of operations performed on craniopagus twins, and was widely acknowledged for his expertise and teaching prowess.

Dr Jorge Chica Ramirez was an Ecuadorian pediatric neurosurgeon in Icaza Bustamante Hospital and an accomplished professional soccer player who died on March 30, 2020 of complications of the virus. Dr Chica was nicknamed as "The Doctor" while playing with Barcelona Sporting Club between 1974 and 1980 while studying medicine.

On April 2, 2020, Dr Jeanne PMR Winaktu, First Admiral (Ret.) of the Indonesian navy passed away at the age of 76 . She was the second highest ranking officer in the Indonesian Navy. She was known as the "Mother of Neurosurgery" in Indonesia.

Two weeks later, on April 17, 2020, Jesus Vaquero Crespo died in Madrid, Spain of

This article is made available for unrestricted research re-use and secondary analysis in any form or by any means with acknowledgement of the original source. These permissions are granted for the duration of the World Health Organization (WHO) declaration of COVID-19 as a global pandemic. 
COVID-induced multi-organ failure. He was a pioneer in the treatment of medullary injuries. A Professor at the Autonomous University of Madrid (UAM), he held the Chair of Neuroscience of the Rafael del Pino Foundation.

Dr Simon Hercules, the Managing Director of New Hope Hospital in Chennai, Tamil Nadu in India died on April 19 at the Apollo Hospital after contracting the virus from a patient. Very sadly, local citizens vandalized the ambulance carrying his body for fear of contracting the virus, and he was buried in Velangadu by his colleagues.

Dr Alexey Filippov, age 51, head of the Department of Neurosurgery at the Alexandrovskaya Hospital died on April 26 at the S.P. Botkin Clinical Infectious Diseases Hospital, St. Petersburg, Russia.

On the same day, Dr Francisco Brito Barrera of the Mexican Social Security Institute died in Cancun, aged 59. He had been looking after COVID-19 cases until a few days prior to contracting the disease.

Dr Ronald Brisman from Columbia University, recognized for his important and comprehensive contributions to the treatment of facial pain, and, coincidentally the father of 2 neurosurgeons passed away on April 20, 2020.

\section{(Continued from previous page)}

${ }^{\S}$ Department of Neurosurgery, Faculty of Medicine, Cairo University, Cairo, Egypt; "Department of Neurosurgery, Emory University School of Medicine, Atlanta, Georgia; "LVR Klinik, Duren, Germany; "Department of Neurosurgery, Brain Tumor Center Zucker School of Medicine, Hofstra/Northwell, North Shore University Hospital, Manhasset, New York; *** Neurological Centre, ABC Medical Center, Mexico City, Mexico; ${ }^{\ddagger \ddagger}$ Bristol Institute of Clinical Neuroscience, Bristol University Hospital, Bristol, United Kingdom; ${ }^{\S \S}$ Henan Provincial People's Hospital, Zhengzhou, China; "Department of Neurosurgery, University of Michigan, Ann Arbor, Michigan; IIIIDepartment of Neurosurgery, Weill Cornell Medicine, New York Presbyterian Hospital, New York New York; \#"Department of Neurosurgery, Indiana University. Indianapolis, Indiana; *** Department of Neurosurgery, Barrow Neurological Institute, Phoenix, Arizona; \#¥¥Department of Neurosurgery, Cannizzaro Hospital, Trauma Centre, Gamma Knife Centre, Catania, Italy; ${ }^{\S \S}$ Cerebrovascular and Skull Base department, Institute of Neurosurgery Asenjo, Providencia, Santiago, Chile; "१११ Emeritus Professor of Neurosurgery, Radboud University Medical Centre, Nijmegen, The Netherlands; IIIIIIDepartment of Neurosurgery, Sir Ganga Ram Institute of Postgraduate Medical

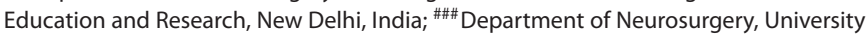
Medicine, Greifswald, Germany; ${ }^{* * * *}$ Department of Neurosurgery, University

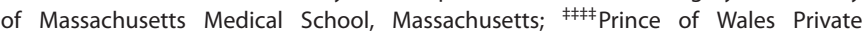
Hospital, Randwick, NSW, Australia; ${ }^{\S \S \S}$ Barrow Neurological Institute, Phoenix, Arizona; จง१ๆ Department of Neurosurgery, Royal Melbourne Hospital, University of Melbourne, Melbourne, Australia; IIIIIIIDepartment of Neurosurgery, Stroke Center, Sapporo Teishinkai Hospital, Sapporo, Japan; \#\#\#Adjunct Professor of Neurosurgery, Federal University of Mato Grosso do Sul Campo Grande, Mato Grosso do Sul, Brazil; ***** Department of Neurosurgery, Fujita Health University Aichi, Toyoake, Japan; ${ }^{\ddagger \neq \neq \neq \ddagger C e n t r e ~ f o r ~ M i n i m a l l y ~ I n v a s i v e ~ N e u r o s u r g e r y, ~ S y d n e y, ~}$

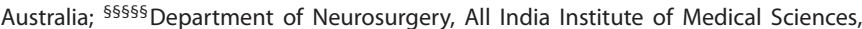
New Delhi, India; กิงจศ Department of Neurosurgery, Paracelsus Medical University

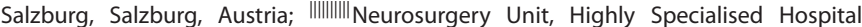
of National Importance "Garibaldi", Catania, Italy; \#\#\#\#Servicio de Neurocirugia, Hospital Universitario Donostia, San Sebastian, Spain; ******Department of Peripheral Nerve Surgery, Functional Neurosurgery and Pain Management Surgery, Clinic for Neurosurgery, Clinical Center of Serbia, Belgrade, Serbia; ${ }^{\neq \neq \neq \neq \neq \neq D i v i s i o n ~ o f ~}$ Neurosurgery, Department of Neurosciences, Reproductive and Odontostomatological

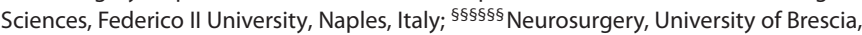
Brescia, Italy; १ศศงจ१ Pituitary/Neuroendocrine Centre, Brigham \& Women's Hospital, Harvard Medical School, Boston, Massachusetts
TABLE. Neurosurgeons Deaths due to COVID-19 (January 1-June 2, 2020)

\begin{tabular}{|lccc|}
\hline Name & Age(yr) & Date of death & Country \\
\hline Liu Zhiming & 51 & February 18 & China \\
Shebl Abdelsalam & 44 & March 14 & Egypt \\
Robin Humphrey & 82 & March 18 & Canada \\
Hugo Diez Perez & 62 & March 20 & Paraguay \\
James T. Goodrich & 73 & March 30 & USA \\
Jorge Chica Ramirez & 68 & March 30 & Ecuador \\
Jeanne PMR Winaktu & 65 & April 2 & Indonesia \\
Jesus Vaquero Crespo & 70 & April 17 & Spain \\
Simon Hercules & 55 & April 19 & India \\
Sameh Zakaria & 42 & April 19 & Egypt \\
Ronald Brisman & 80 & April 20 & USA \\
Alexey Filippov & 51 & April 20 & Russia \\
Francisco Brito Barrera & 58 & April 26 & Mexico \\
Ronald Brisman & 80 & May 4 & USA \\
Mahmoud Mahmoud El & 59 & May 4 & Egypt \\
Hendawy & & & \\
Lukas Budiono Atmaji & 78 & May 5 & Indonesia \\
Edilson Toshio Shoji & 44 & May 14 & Brazil \\
Marino Purizaca Amaya & 67 & May 31 & Peru \\
Tahir Khalili & 38 & June 2 & Afghanistan \\
\hline
\end{tabular}

Others who succumbed included the Egyptian neurosurgeon Prof Mahmoud Mahmoud El Hendawy, Professor at the Al Azhar University in Cairo on May 4, Dr Lukas Budiono Atmaji, Senior Neurosurgeon and Lecturer at the Indonesia University in Jakarta, Indonesia on May 5, and Edilson Toshio Shoji, of the Hospital (Holy House) Santo Amaro in San Paolo, Brazil on May 14. Recently, 2 more neurosurgeons succumbed to COVID-19 on May 31 and June 2, respectively. Dr Marino Purizaca who worked in Ministry of Health, Sullana, Peru and Dr Tahir Khalili who worked in Pirzad Neurosurgery Hospital, in Afghanistan made the supreme sacrifice.

We would be remiss if we did not note the passing of neurosurgeons who died of other causes during the pandemic. They include Kazem Fathie, past President and Chair of the American Academy of Neurological and Orthopaedic Surgeons (AANOS) died on April 19, aged 91. Robin Paul Humphreys of Peterborough, Ontario in Canada, died of injuries sustained in a fall at age 82 . He had been President of the American Society of Pediatric Neurosurgery and the International Society for Pediatric Neurosurgery. Sameh Zakaria died of glioblastoma in Egypt. Shebl Abdelsalam sustained a cardiac arrest.

The passing of each one of these individuals represents a loss to the profession, as well as to family, friends and colleagues. Our condolences go out to all who have suffered losses around the world. Although the pandemic appears to be on the wane in many locations, it is far from over. Neurosurgeons remain at the front line of patient care. ${ }^{1}$ It is important for neurosurgeons to protect themselves and their families. We remember, commemorate, appreciate and celebrate those who have succumbed, and, 
no less, those who continue to risk the exposure incumbent on providing patient care generously, bravely, and at the level to which the neurosurgical community is accustomed.

\section{Disclosures}

The authors have no personal, financial, or institutional interest in any of the drugs, materials, or devices described in this article.

\section{REFERENCE}

1. Daci R, Natarajan SK, Johnson MD. Letter: safety considerations for neurosurgical procedures during the COVID-19 pandemic. Neurosurgery. published online: 2020 (doi:10.1093/neuros/nyaa196). 